\title{
Examination of Behavioral Traits of Monocultures and Polycultures of Two Different Trout Species (Oncorhynchus mykiss, Salmo sp.) at Different Ratios Depending on Various Factors
}

\author{
Boran KARATAŞ*, Muhammed ARABACI
}

Van Yüzüncü Yıl University, Faculty of Fisheries, Department of Aquaculture, Van, Turkey ORCID ID: Boran KARATAŞ: http://orcid.org/0000-0003-4353-1293; Muhammed ARABACI: https://orcid.org/0000-0002-2462-6441

\begin{abstract}
Received: 14.09 .2021
Accepted: 10.12 .2021

Published online: 13.12 .2021

Issue published: 31.12 .2021

Abstract: The present study aimed to determine both the effects of monocultures of rainbow trout $(\mathrm{R})$ and brown trout (B) and polycultures (R 75\%-B 25\%; R 66\%-B 34\% and R 50\%-B 50\%) on behavior. In the study, the area used vertically by the fish in the tank, the mobility rate of fish in the tank, the rate of tendency of fish in eating as soon as they were fed, whether the fish test the feed, the interspecies feed competition, the time they start to take the first feed, the duration of the feed consumption of the fish and the feed area of the fish have been considered as behavioral evaluation criteria. The trout were monitored with a camera to determine their behavior. Considering all behavioral criteria, the best polyculture rate was determined as $\mathrm{R} 66 \%$ B 34\%. Brown trout were found to be more mobile and exhibit more relaxed behavior compared to other groups in polyculture. In addition, interspecies feed competition was mostly encountered in this group. As a result, in this study, in which two different trout species were monocultured and treated at different polyculture ratios, the main factor causing behavioral change in fish was found to be the different stocking rates of fish to each other in the same tank. Different rates applied in polyculture caused unpredictable changes in behavior in both species. The ratio of fish used in polyculture was found to be a considerable factor affecting the final product and their behavior for aquaculture.
\end{abstract}

Keywords: Behavioral change, rainbow trout, brown trout, polyculture.

\section{İki Farklı Alabalık Türünün (Oncorhynchus mykiss, Salmo sp.) Monokültürleri ile Farklı} Oranlarda Polikültürlerinin Çeşitli Faktörlere Bağlı Davranış Özelliklerinin İncelenmesi

\begin{abstract}
Öz: Bu çalışmada gökkuşağı alabalığı $(\mathrm{G})$ ve kahverengi alabalığın (K) monokültürleri ile farklı oranlarda (G\% 75-K\%25; G\%66K\%34 ve G\%50-K\%50) polikültürlerinin davranış üzerine etkilerinin belirlenmesi amaçlanmıştır. Çalışmada balıkların; tankta dikey olarak kullandığı bölge, tanktaki hareketlilik oranları, yemin ilk verildiği anda yeme karşı ilgi yüzdesi, yemi test edip etmediği, türler arası yem rekabeti, ilk yem almaya başlama süresi, yemi tüketme süresi ve yem aldığı bölge davranış değerlendirme ölçütleri olarak dikkate alınmıştır. Alabalıkların davranışlarını belirlemek için kamera kayıtları kullanılmıştır. Tüm davranış ölçütleri dikkate alındığında en iyi polikültür oranı G\%66-K\%34 olarak belirlenmiştir. Bu gruptaki kahverengi alabalıkların polikültürdeki diğer gruplara kıyasla daha hareketli olduğu ve daha rahat davranış sergiledikleri görülmüştür. Ayrıca türler arası yem rekabeti de en fazla bu grupta görülmüştür. Sonuç olarak iki farklı alabalık türünün monokültürünün ve farklı oranlarda polikültürünün yapıldığı bu çalışmada balıklardaki davranış değişikliğine sebep olan temel etken, balıkların aynı tanktaki birbirlerine olan farklı stoklama oranlarıdır. Polikültürde uygulanan farklı oranların iki türün davranışlarında önceden tahmin edilemeyecek şekilde değişikliklere sebep olmuştur. Polikültürde kullanılan balıkların birbirlerine olan oranları, yetiştiricilikte davranışı nihai ürünü etkileyen ve dikkate alınması gereken önemli bir faktördür.
\end{abstract}

Anahtar kelimeler: Davranış değişikliği, gökkuşağı alabalığı, kahverengi alabalık, polikültür.

\section{Introduction}

Changes in environmental conditions in aquaculture may cause several differences in fish behavior. Observation and evaluation of these differences are crucial for aquaculture producers and experts. Many systems, therefore, have been developed by researchers to evaluate fish behavior (Hong, \& Zha, 2019; Han et al., 2020). Due to cost effectiveness and their reliability, video technologies that form the basis of most of these systems are widely applied in both research and commercial aquaculture facilities to monitor and analyze fish behavior (Kane et al., 2004; Stien et al., 2007; Wagget \& Buskey, 2007; Salierno et al., 2008; Papadakis et al., 2012; Papadakis et al., 2014; Hong \& Zha, 2019). Moreover, monitoring and analyzing the fish behavior provide economic benefits for fish farmers (Stien et al., 2007; Papadakis et al., 2014). As in all farming fields, an important purpose in aquaculture is to obtain maximum product from the unit area with the least cost. Although it may be underestimated, the factors that cause sudden changes in fish behavior may affect the profitability of the business (Karataş, 2015). Understanding fish behavior, therefore, is crucial for the effective management of aquaculture facilities (Pinkiewicz et al., 2011).

Researchers have conducted many comprehensive studies on feeding, swimming, and group behavior of fish. In addition to investigating fish interactions with other species, they examined fish behavior under environmental stress and in polyculture aquacultures ( $\mathrm{Xu}$ et al., 2006; Delcourt et al., 2009; Sadoul et al., 2014; Karataş, 2015; Føre et al., 2018; Li et al., 2020). These studies on fish behavior have contributed to the development of healthy 
aquaculture practices in terms of improving breeding conditions, identifying individual or environmental negativities. Studies on the behavior of cultured fish species in polyculture breeding studies, however, is extremely scarce. Polyculture breeding studies mostly focused on the growth and survival rates of the cultured fish rather than their behavior (Barki \& Karplus, 2016). However, the behavior of the fish in the polyculture studies may significantly affect the breeding results (e.g., growth, feed consumption, and etc.) (Rahman \& Verdegem, 2010; Karataş, 2015).

In this study, the effects of monocultures of rainbow trout $(\mathrm{R})$ and brown trout (B), which are two carnivorous species cultivated in Turkey, and polycultures (R 75\%-B $25 \%$; R $66 \%$-B 34\% and R 50\%-B 50\%) on behavior are aimed to be investigated in a comparative manner.

\section{Material and Methods}

This study was carried out at Fisheries Research and Application Facility, Yüzüncü Yıl University Research and Application Farm Directorate. The study was approved by the Animal Experiments Local Ethics Committee (No: 27552122-80) of Van Yüzüncü Yil University. In the study, rainbow trout (Oncorhynchus mykiss) and stream ecotype of brown trout (Salmo sp.) were used. The fish used in the research were obtained from the Avcil Trout Farm in Bitlis Province. The study was carried out between July and October 2014. In the current examination, ten PVC aquaculture tanks with a volume of 500 liters were used. During the study, the amount of dissolved oxygen in water and the temperature and $\mathrm{pH}$ of the water were measured on daily basis just after 30 minutes of feeding. During the study, fish were fed with $2 \mathrm{~mm}$ and $3 \mathrm{~mm}$ trout grower feed produced by a private company (Skretting) twice every day, once in the morning and once in the evening. To determine the exact environmental and food consumption effects of polyculture, "over nutrition" method was used as nutritional regime. To prevent the feed to affect the behavior of the fish and to be ever present in the environment whenever they needed, the feed was delivered more than the amount required by the fish. During this experiment, the amount of dissolved oxygen ranged from $5.8 \mathrm{mg} / \mathrm{L}$ to $7.4 \mathrm{mg} / \mathrm{L}$ whereas the $\mathrm{pH}$ of water varied from 7.9 to 8.1 . While the temperature was about $18^{\circ} \mathrm{C}$ at the beginning of the experiment, it was measured as about $15^{\circ} \mathrm{C}$ at the end. The water flow rate of tanks was adjusted to an average of $2 \mathrm{~L} / \mathrm{min}$ in the present study.

A total of 140 rainbow trout $(24.7 \pm 0.2 \mathrm{~g})$ and 100 brown trout $(41.8 \pm 0.8 \mathrm{~g})$ were tested in the study. The weight difference between the rainbow trout and brown trout utilized in the current experiment was found higher than the intended level. This is because the trial layout was corrupted seven times due to the difficulties in material supply, the deterioration of water quality, and the recurrent diseases. Five different stockings were applied at different rates and each stocking rate was assessed as a group. These groups were planned as two replications. Rainbow trout (R) and Brown trout (B) ratios in polyculture were established in line with the recommendations of the commercial fish farms. A total of 240 fish were used and 24 fish were placed in each group. Table 1 shows the groups applied in the current study and the stocking rates.
Table 1. The groups applied in the current study and stocking rates.

\begin{tabular}{ll}
\hline Groups & Stocking Rates (Species and number of fish in groups) \\
\hline $\mathrm{R}$ & $100 \%$ Rainbow Trout (24) \\
$\mathrm{B}$ & $100 \%$ Brown Trout (24) \\
R50B50 & $50 \%$ Rainbow Trout (12) $+50 \%$ Brown Trout (12) \\
R66B34 & $66.6 \%$ Rainbow Trout (16) $+33.3 \%$ Brown Trout (8) \\
R75B25 & $75 \%$ Rainbow Trout (18) $+25 \%$ Brown Trout (6) \\
\hline
\end{tabular}

The study was launched after 10 days of adaptation of the fish. Then, the study was proceeded for another 80 days. In order to examine the effects of two different trout breeding in the same environment at different rates on the behavior, the fish behaviors in the experimental tanks were monitored every three weeks using a GoPro Hero II underwater camera during and after feeding. Video cameras were placed in the tanks just 5 minutes before the feeding procedure and recorded until the camera batteries died (approximately 60 minutes). The criteria for the behavior of the trout during and after feeding procedures were specified according to the results of the comparative monitoring of the groups.

In the study, to determine the behavior of the fish, the edges of the experimental tanks were marked creating white rings at $15 \mathrm{~cm}$ intervals. The bottom of the tank was calibrated as $0 \mathrm{~cm}$ whereas the surface of the tank was adjusted as $50 \mathrm{~cm}$. The water level in each tank was set to $40 \mathrm{~cm}$ (Fig. 1).

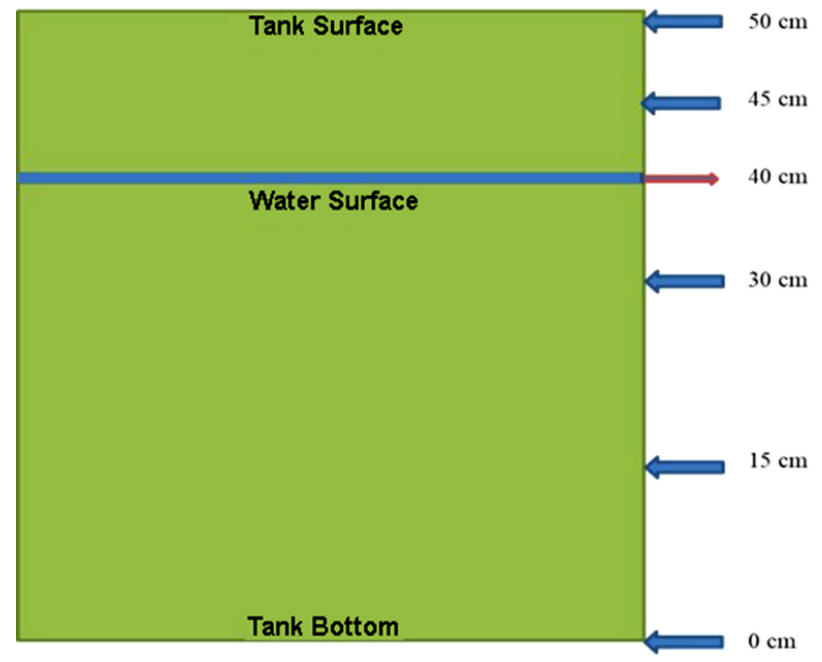

Figure 1. Markings made at $15 \mathrm{~cm}$ intervals from the bottom of the tank towards the surface of the tank to determine the vertical use of the fish in the tank.

In the present study, data on behavior were obtained watching the camera records. Then, the records were assessed to respond to the quantitative behavioral criteria stated below. These assessments were carried out by the same observer to be consistent through the current experiments. Since it was difficult to identify fish in camera records at first glance, the videos were watched repeatedly at first and; then, the assessments were carried out after becoming familiar with these records.

In the study, 8 behavioral evaluation criteria, which were quantitatively classified as discussed below, were carried out. 


\section{(i) The area used vertically by the fish in the tank;}

In monoculture farming, brown trout generally use the bottom of the tank whereas rainbow trout mostly use the middle part of the tank. In some polyculture groups, however, the distribution of fish in the water column varied for both trout species. This situation, therefore, was defined as the area used vertically by the fish in the tank and this has been digitized in centimeters from the bottom of the tank upwards.

\section{(ii) The mobility rate of the fish in the tank;}

In monoculture aquaculture, rainbow trout are usually very active in the tank and they tend to swim quickly and actively around the tank. Brown trout, on the other hand, are not very mobile in the tank compared to rainbow trout and even some of them tend to stay still on the bottom of the tank. This behavior of the fishes, however, shows alterations in polyculture groups as they compete with each other for food and area. These alterations in the movement of fish were observed particularly in brown trout in polyculture groups. This situation has defined as the mobility rate of fish in the tank. Based on the number of fish in the polyculture groups, the number of fish swimming quickly and actively during and after feeding were calculated. Then, these alterations were assessed as minimum +, maximum +++++ based on numerical values.

(iii) The rate of tendency of the fish in eating as soon as they were fed;

In monoculture aquaculture, while the majority of rainbow trout tend to eat feed quickly and actively (like gobbling and rushing for feed), most of the brown trout remain stable and do not actively eat feed. This situation differs in polyculture groups. Based on the number of fish in the polyculture groups, the number of fish tending to feed (regardless of whether the fish take the feed or not) was determined and given as percentage.

\section{(iv) Whether the fish test the feed;}

In monoculture, the brown trout which did not show interest in the feed as soon as they were fed tested the feed. This test involved playing with the feed, gathering the feed using their tails, and hanging around the feed. In this way, whether the fish test the feed was evaluated as "yes" or "no".

\section{(v) The time the fish start to take the first feed;}

The time after the start of feeding the fish was expressed as the time the fish start to take the first feed and this was given in minutes (in other words, it was determined in what minute the fish started to take the first feed). This situation showed alterations in different video records taken at different times for the same group. Therefore, the time the fishes start to take the first feed was given as the minimum start minute and the maximum start minute.

\section{(vi) The interspecies feed competition;}

In polyculture groups, on the other hand, the interspecies competition during the feed intake was assessed as present or not present.

\section{(vii) The duration of the feed consumption of the fish;}

The period between the first and last feed intake of the fish was determined as the duration of the feed consumption.
This period was evaluated in minutes. This also varied in different video records taken at different times for the same group. Therefore, the duration of the feed consumption of fishes was given as the minimum feed consumption time and the maximum feed consumption time.

\section{(viii) The feed area of the fish;}

In monoculture farming, brown trout commonly grab the feed from the bottom of the tank (ground) whereas rainbow trout take the feed from both the tank bottom (ground) and the water column. In some polyculture groups, however, the feed area differed for both trout species. This was defined as the feed area of the fishes and considered starting from the bottom of the tank or water column.

\section{Results}

The findings of the present study on the effects of two different trout species farming in the same environment at different rates on behavior were evaluated separately for each group and given in figures and tables. The areas used vertically by the fish in the test tanks were given in Figure 2 and Table 2.

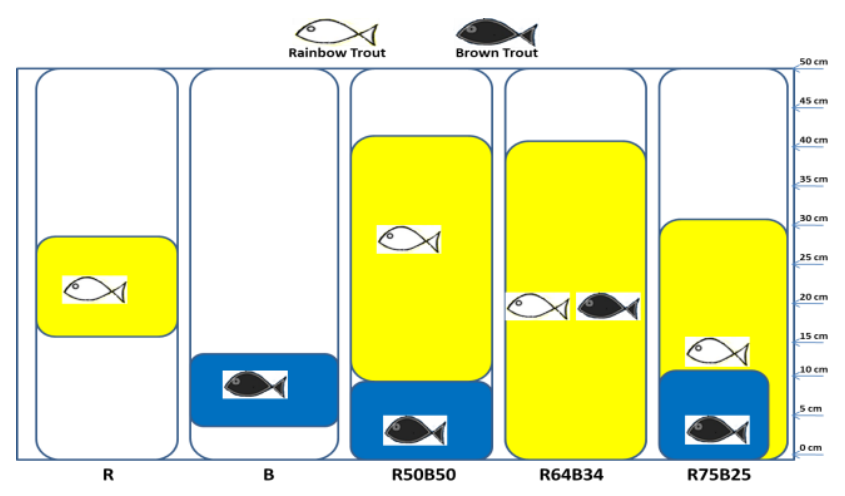

Figure 2. The areas used vertically by the fish in the test tanks.

The findings on the areas used vertically by the fish and the mobility rate of fish in the tanks were given in Table 2.

The findings on the rate of tendency of the fish in eating as soon as they were fed, whether the fish test the feed, the time the fish start to take the first feed were given in Table 3.

The findings on the interspecies feed competition, the duration of the feed consumption of the fish, and the feed area of the fish were given in Table 4 .

\section{Discussion and Conclusions}

In the present study, two different trout species in experimental tanks were monitored using a GoPro underwater camera during and after feeding to examine the effects of breeding (monoculture and polyculture) of these fish in the same environment at different rates on behavior. In line with the behavioral results obtained, when considering the areas used vertically by the fish in the tank it was observed that the monocultured rainbow trout actively used every part of the tank and mainly preferred the areas between $15-30 \mathrm{~cm}$ from the bottom of the tank. The monocultured brown trout, on the other hand, mostly used the area of $5-15 \mathrm{~cm}$ and rarely preferred the area of $20-25 \mathrm{~cm}$ from the bottom of the tank. This 
situation, however, varied in other groups when polyculture was performed. Unpredictable behavior patterns were even encountered in each group. In R50B50 group where polyculture was performed, it was observed that rainbow trout used the area of $10-40 \mathrm{~cm}$ whereas brown trout utilized the area of $0-10 \mathrm{~cm}$ from the bottom of the tanks. This shows that two different trout species recognized each other, allocated the tank between themselves, and did not poach on each other's territory. In the polyculture of rainbow trout and brown trout in the R66B34 group, both species in the tanks with a water height of $50 \mathrm{~cm}$ mainly used the areas of $0-40 \mathrm{~cm}$ from the bottom of the tanks. This demonstrates that these different species were completely accustomed to each other and shared every part of the tank. In the R75B25 group, it was observed that the rainbow trout mainly used the area of 0 $30 \mathrm{~cm}$ whereas brown trout preferred the area of $0-10 \mathrm{~cm}$ from the bottom of the tank. This situation can be evaluated as those two different trout species allocated the tank between themselves; however, rainbow trout also actively disturbed the area of brown trout; that is, they pressured on the brown trout.

Table 2 . The areas used vertically by the fish and the mobility rate of fish in the tanks.

\begin{tabular}{|c|c|c|c|}
\hline Groups & Fish species & $\begin{array}{l}\text { The areas used vertically by the fishes } \\
\text { (maximum depth: } 50 \mathrm{~cm} \text { ) }\end{array}$ & $\begin{array}{l}\text { The mobility rate of fishes in the } \\
\text { tanks (maximum value }+++++ \text { ) }\end{array}$ \\
\hline $\mathrm{R}$ & Rainbow trout & $\begin{array}{l}\text { All areas of the water column in the tank } \\
\text { (Mostly between } 15-30 \mathrm{~cm} \text { ) }\end{array}$ & ++++ \\
\hline B & Brown trout & $\begin{array}{l}\text { The distance between } 0-25 \mathrm{~cm} \\
\text { (Mostly between } 5-15 \mathrm{~cm} \text { ) }\end{array}$ & ++-- \\
\hline \multirow{2}{*}{ R50B50 } & Rainbow trout & Between $10-40 \mathrm{~cm}$ & ++++ \\
\hline & Brown trout & Between $0-10 \mathrm{~cm}$ & +++-- \\
\hline R66B34 & Rainbow trout/Brown trout & Between 0-40 cm/Between 0-40 cm & $+++++/+++++$ \\
\hline R75B25 & Rainbow trout/Brown trout & Between 0-30 cm/Between 0-10 cm & $+++++/+++--$ \\
\hline
\end{tabular}

Table 3. The rate of tendency of the fish in eating as soon as they were fed whether the fish test the feed and the time the fish start to take the first feed.

\begin{tabular}{|c|c|c|c|c|}
\hline Groups & Fish species & $\begin{array}{l}\text { The rate of tendency of fishes in eating as } \\
\text { soon as they were fed }\end{array}$ & $\begin{array}{l}\text { Whether the fishes test the feed } \\
\text { (Yes/No) }\end{array}$ & $\begin{array}{l}\text { The time fishes start to take the } \\
\text { first feed (Minimum-Maximum) }\end{array}$ \\
\hline $\mathrm{R}$ & Rainbow trout & $90 \%$ interested when fed & No & 0 min (Started straight away) \\
\hline B & Brown trout & $20 \%$ interested when fed & $\begin{array}{l}\text { Yes (Playing with the feed, } \\
\text { gathering the feed using their tails) }\end{array}$ & After $20-30 \mathrm{~min}$ \\
\hline \multirow[t]{2}{*}{ R50B50 } & Rainbow trout & $90 \%$ interested when fed & No & 0 min (Started straight away) \\
\hline & Brown trout & $\begin{array}{l}\text { Not interested when fed. } \\
50 \% \text { interested after 5-10 min }\end{array}$ & No & Between 5-10 min \\
\hline \multirow[t]{2}{*}{ R66B34 } & Rainbow trout & $90 \%$ interested when fed & No & 0 min (Started straight away) \\
\hline & Brown trout & $90 \%$ interested when fed & No & 0 min (Started straight away) \\
\hline \multirow[t]{2}{*}{ R75B25 } & Rainbow trout & $90 \%$ interested when fed & No & 0 min (Started straight away) \\
\hline & Brown trout & $\begin{array}{l}\text { Not interested when fed. } \\
60 \% \text { interested after } 25-30 \mathrm{~min}\end{array}$ & No & Between $20-25 \mathrm{~min}$ \\
\hline
\end{tabular}

Table 4. The interspecies feed competition, the duration of the feed consumption of the fish, and the feed area of the fish.

\begin{tabular}{|c|c|c|c|c|}
\hline Groups & Fish species & $\begin{array}{l}\text { The interspecies feed competition } \\
\text { (present/not present) }\end{array}$ & $\begin{array}{l}\text { The duration of the feed } \\
\text { consumption of fishes } \\
\text { (minimum-maximum) }\end{array}$ & $\begin{array}{l}\text { The feed area of the } \\
\text { fishes }\end{array}$ \\
\hline $\mathrm{R}$ & Rainbow trout & - & Between 20- 25 min & $\begin{array}{c}\text { Water column and tank } \\
\text { bottom }\end{array}$ \\
\hline B & Brown trout & - & Between $30-40(+)^{*} \min$ & Tank bottom \\
\hline \multirow[t]{2}{*}{ R50B50 } & Rainbow trout & Present & Between $15-20 \mathrm{~min}$ & $\begin{array}{c}\text { Water column and tank } \\
\text { bottom }\end{array}$ \\
\hline & Brown trout & Present & Between $35-55(+)^{*}$ min & Tank bottom \\
\hline \multirow[t]{2}{*}{ R66B34 } & Rainbow trout & Present & Between 25-30 min & $\begin{array}{l}\text { Water column and tank } \\
\text { bottom }\end{array}$ \\
\hline & Brown trout & Present & Between 25-30 min & $\begin{array}{c}\text { Water column and tank } \\
\text { bottom }\end{array}$ \\
\hline \multirow[t]{2}{*}{ R75B25 } & Rainbow trout & Present & Between 20-25 min & $\begin{array}{c}\text { Water column and tank } \\
\text { bottom }\end{array}$ \\
\hline & Brown trout & Not present & Between $35-40(+)^{*} \min$ & Tank bottom \\
\hline
\end{tabular}

* Recording could not be continued due to the camera running out of charge. However, the feed consumption of the fish continued to be monitored by the researcher and it was observed that the feed consumption also continued after the video recording.

In the present study, the application of polyculture caused changes in the areas used vertically by the fish in the tanks. Similarly, Rahman \& Verdegem (2010) investigated the polyculture of two different carp species (Labeo calbasu and Cirrhinus cirrhosus) in their study. They stated that both species were fed from the bottom of the tank, however, this situation changed in polyculture due to the competition between species. In addition, they reported that one of the species, L. calbasu, started feeding from both the tank bottom and the water column. In another study conducted by Barki \& Karplus (2016), the behavior of tilapia and crayfish in polyculture was examined and it was reported that while tilapia species used every part of the tank in monoculture, they preferred to use mostly the water 
column due to the presence of crayfish in polyculture.

Assessing the study groups in terms of the mobility rate of the fish in the tank, it was observed that the monocultured rainbow trout were very active in the tank. Moreover, it was noticed that the fishs were swiftly and actively swimming around the tank. On other hand, it was observed that monocultured brown trout were not very active in the tank and some of them were dormant on the bottom of the tank. Rainbow trout and brown trout in the R66B34 group, however, were very active in the tank. In particular, the brown trout, which were calmer and shier, were found to be very comfortable in this group (R66B34) like rainbow trout. In the other two groups (R50B50, R75B25), the brown trout exhibited recessive behavior similar to the group B.

The polyculture application conducted in this study caused changes in the mobility rate of the fish in the tanks. In a previous study showing similarities with the results of this study, Rahman \& Verdegem, (2010) investigated the polyculture of two different carp species (Labeo calbasu and Cirrhinus cirrhosus) and they reported that one of the species (C. cirrhosus) exhibited recessive behavior in polyculture compared to monoculture while the other species ( $L$. calbasu) was more active. As a result, they asserted that this situation has a positive effect on the growth of L. calbasu species. In another study, Barki \& Karplus (2016) investigated polycultures of tilapia and crayfish and reported that tilapia species were more active in polyculture compared to monoculture and this increased the growth of tilapias.

When the study groups were evaluated in terms of the rate of tendency of the fish in eating as soon as they were fed, it was observed in monocultured rainbow trout that most of the fish (about 90\%) showed interest in eating quickly and actively (by attacking the bait) as soon as the feeding process started. In monocultured brown trout, it was observed that most of the fish (about $80 \%$ ) remained stable after the start of feeding and they did not show interest in feeding quickly and actively. This shows that the brown trout were very sensitive and tested the feed (picking the feed up by wiggling it using their tails). After examining the video records, it was determined that these fish started to eat the feed in small amounts during the first 20-30 minutes after feeding and they aggregated the feed in an area on the bottom of the tank using their tails and then tested. After this process, testing and recognizing the feed, it was observed that the feed intake of the fish increased. It was monitored that the rainbow trout in all groups did not test the feed and reckon the objects thrown into the tanks as feed. The brown trout in the R66B34 group were found to be very comfortable towards the feed like rainbow trout. This may indicate that the brown trout in this group learned this behavior from rainbow trout. In the other two groups (R50b50, R75B25), it was observed that the brown trout waited for a while after feeding and then took the feed (Table 3). The fish in these two groups (R50B50, R75B25), however, did not test the feed. The rainbow trout's ingestion of the feed may have caused the brown trout to take the bait without testing it.

In this study, the application of polyculture caused changes in the percentage of interest of the fish towards the feed at the first feeding. Similarly, Sirtkaya (2013) compared the growth performance, daily feed consumption, and feed conversion ratios of monocultured and polycultured rainbow trout (Oncorhynchus mykiss) and turbot (Psetta maxima). She observed that monocultured turbot fish were relatively less active than turbot in the polyculture group, while turbot in the polyculture group were more active in feed intake. Furthermore, Sirtkaya (2013) reported that the fish in the polyculture group grouped among themselves, stood in different directions, and were positioned opposite to each other on both sides of the tank. In another polyculture study, it was reported that due to presence of the crayfish at the bottom of the tank, tilapias moved faster in the water column in polyculture compared to monoculture (Barki \& Karplus, 2016). It was also stated that the tilapias attacked to the feed as a group and consumed more feed before the feed sinks into the tank bottom (Barki \& Karplus, 2016).

When the study groups were evaluated in terms of the interspecies feed competition, feed competition between fish in mixed farms was observed. In the R50B50 group, the rainbow trout, which did not leave their area during non-feeding periods, put pressure on brown trout by entering their area to take the feed on the ground during feeding. Under these circumstances, the brown trout remained stable and formed a protection area by covering the feed. In the R66B34 group, on the other hand, there was a competition between brown trout and rainbow trout during feeding due to the feed intake from both the ground and the water column. It was observed that the fish chased each other during feed intake and prevented each other taking the feed. In the R75B25 group, some of the brown trout (approximately 20\%) approached the feed 510 minutes after feeding; however, the rainbow trout did not allow them and prevented the brown trout from approaching the feed. This situation in the R75B25 group can be interpreted that a sense of competition was formed in rainbow trout however this feeling did not form in the brown trout because of not attempting to take the feed as they submitted themselves to this situation.

Some studies reported that even albinism is a factor affecting the aquaculture process in rainbow trout farming. For example, when normal pigmented rainbow trout and albino rainbow trout were reared in separate environments, the growth and feed utilization of albino rainbow trout were not decent. When they were reared in the same pond; however, albinos competed with normal rainbow trout for feed intake and subsequently the growth of albinos increased (Okumuş et al., 2001).

Considering the study groups with regards to the duration of the feed consumption of the fish, this duration showed differences between groups. While rainbow trout did not consume the feed after the first 25 minutes in all groups, this period was 30-40(+) minutes in monocultured brown trout. This period, however, shortened in some groups in polyculture. The shortening of feed consumption time of brown trout in polyculture groups could be due to learning from rainbow trout.

Considering the behaviors observed in all groups during the current study, it was observed that the R66B34 group exhibited the most comfortable behavior among the brown trout. Nevertheless, this kind of comfortable behavior was not observed in groups with other brown trout. However, some differences were observed in the motility rates, the areas used vertically in the tank, the rate 
of tendency of fish in eating as soon as they were fed, the areas where they were fed and the duration of the feed consumption of brown trout in polyculture. On the other hand, when the behavioral differences in rainbow trout were evaluated in the present study, it is determined that behavioral differences occurred in the mobility rates of the fish in the tank, the area used vertically by the fishes in the tank, and the duration of the feed consumption of fishes. Indeed, in our publication containing other results of the same experiment, where the data on growth and feed evaluation conducted in detail, Karataş et al. (2017) reported that the feed consumption amounts and growth rates of brown trout in all polyculture groups increased comparing to monoculture of brown trout due to feed competition between fish. Karataş et al. (2017) recommended especially the R66B34 group along with other polyculture groups rather than the monoculture of brown trout to fish farmers for rapid growth of brown trout. This is because, when this ratio of polyculture was applied, brown trout's comfortable behavior like rainbow trout reduced the stress of brown trout and increased feed competition and feed consumption. In addition, in the study of Karataş et al. (2017), where monoculture and polyculture of rainbow trout and brown trout were experimented, it was reported that the highest amount of final product was observed in monoculture of rainbow trout. Therefore, they recommended monoculture of rainbow trout rather than polyculture of rainbow trout with brown trout to the fish farmers who desires the largest amount of final product.

In conclusion, in the present study, in which two different trout species were monocultured and polycultured at different rates, the main factor causing behavioral changes in trout was the ratio of fish to each other. Different ratios applied in polyculture caused unpredictable changes in behavior in both fish species in the current examination. Therefore, the ratio of the fishes used in polyculture is a significant factor affecting the final product.

Acknowledgements: We would like to thank Zeynel Avcil and Soran Avcil (Avcil Trout Facility), Muhittin Esen (Mis Trout Facility) and Selim Mantaş (Yeşilsu Trout Facility) for their support in providing study materials. This paper is based on a part of MSc dissertation of the first author.

Ethics committee approval: This study was performed in accordance with ethical standards of animal experiments. Legal research ethics committee approval permissions for the study were obtained from the Van Yüzüncü Yll University, Animal Experiments Local Ethics Committee (No: 27552122-80).

Conflict of interest: The authors declare that there is no conflict of interest.

\section{References}

Barki, A., \& Karplus, I. (2016). The behavioral mechanism of competition for food between tilapia (Oreochromis hybrid) and crayfish (Cherax quadricarinatus). Aquaculture, 450, 162-167. https://doi.org/10.1016/j.aquaculture.2015.07.031

Delcourt, J., Becco, C., Vandewalle, N., \& Poncin, P. (2009). A video multitracking system for quantification of individual behavior in a large fish shoal: advantages and limits. Behavior Research Methods, 41(1), 228235. https://doi.org/10.3758/BRM.41.1.228

Han, F., Zhu, J., Liu, B., Zhang, B., \& Xie, F. (2020). Fish Shoals Behavior Detection Based on Convolutional Neural Network and Spatiotemporal Information. IEEE Access, 8, 126907-126926. https://doi.org/10.1109/ACCESS.2020.3008698
Føre, M., Frank, K., Norton, T., Svendsen, E., Alfredsen, J.A., Dempster, T., \& Berckmans, D. (2018). Precision fish farming: A new framework to improve production in aquaculture. Biosystems Engineering, 173, 176193. https://doi.org/10.1016/j.biosystemseng.2017.10.014

Hong, X., \& Zha, J. (2019). Fish behavior: A promising model for aquatic toxicology research. Science of the Total Environment, 686, 311-321. https://doi.org/10.1016/j.scitotenv.2019.06.028

Kane, A.S., Salierno, J.D., Gipson, G.T., Molteno, T.C., \& Hunter, C. (2004). A video-based movement analysis system to quantify behavioral stress responses of fish. Water Research, 38(18), 3993-4001. https://doi.org/10.1016/j.watres.2004.06.028

Karataş, B. (2015). Gökkuşağı alabalığı (Oncorhynchus mykiss) ve kahverengi alabalığın (Salmo trutta ssp) farklı oranlarda birlikte yetiştiriciliğinin büyüme performansı, yem değerlendirme ve davranış üzerine etkileri (398725). Retrieved from https://tez.yok.gov.tr/UlusalTezMerkezi/giris.jsp

Karataş, B., Arabacı, M., \& Önalan, Ş. (2017). Comparison of rainbow trout (Oncorhynchus mykiss) and brown trout (Salmo trutta ssp) dual culture in different ratios and growth performances. Pakistan Journal of Zoology, 49(6). https:// doi.org/10.17582/journal.pjz/2017.49.6.2257.2261

Li, D., Wang, Z., Wu, S., Miao, Z., Du, L., \& Duan, Y. (2020). Automatic recognition methods of fish feeding behavior in aquaculture: A review. Aquaculture, https://doi.org/10.1016/j.aquaculture.2020.735508

Okumuş, İ., Değirmenci, A., Başçınar, N., \& Çelikkale, M.S. (2001). Comparative performance approximate biochemical composition and consumer preference of albino and normally pigmented varieties of rainbow trout (Oncorhynchus mykiss). Turkish Journal of Fisheries and Aquatic Sciences, 1, 23-28.

Papadakis, V.M., Papadakis, I.E., Lamprianidou, F., Glaropoulos, A., \& Kentouri, M. (2012). A computer-vision system and methodology for the analysis of fish behavior. Aquacultural Engineering, 46, 53-59. https://doi.org/10.1016/j.aquaeng.2011.11.002

Papadakis, V.M., Glaropoulos, A., \& Kentouri, M. (2014). Sub-second analysis of fish behavior using a novel computer-vision system. $\begin{array}{llll}\text { Aquacultural Engineering, 62, 36-41. } & \end{array}$ https://doi.org/10.1016/j.aquaeng.2014.06.003

Pinkiewicz, T.H., Purser, G.J., \& Williams, R.N. (2011). A computer vision system to analyse the swimming behavior of farmed fish in commercial aquaculture facilities: A case study using cage-held Atlantic salmon. $\begin{array}{lll}\text { Aquacultural Engineering, 45(1), 20-27. } & \end{array}$ https://doi.org/10.1016/j.aquaeng.2011.05.002

Rahman, M.M., \& Verdegem, M., (2010). Effects of intra-and interspecific competition on diet, growth and behavior of Labeo calbasu (Hamilton) and Cirrhinus cirrhosus (Bloch). Applied Animal Behavior Science, 128(1-4), 103-108. https:// doi.org/10.1016/j.applanim.2010.09.015

Sadoul, B., Mengues, P.E., Friggens, N.C., Prunet, P., \& Colson, V. (2014). A new method for measuring group behaviors of fish shoals from recorded videos taken in near aquaculture conditions. Aquaculture, 430, 179-187. https://doi.org/10.1016/j.aquaculture.2014.04.008

Salierno, J.D., Gipson, G.T., \& Kane, A.S. (2008). Quantitative movement analysis of social behavior in mummichog, Fundulus heteroclitus. Journal of Ethology, 26(1), 35-42. https://doi.org/10.1007/s10164-0060027-7

Sırtkaya, N. (2013). Saf ve karısık olarak yetiștirilen gökkusağı alabalığı (Oncorhynchus mykiss) ve kalkan balığı (Psetta maxima)'nın büyüme performanslarının karşılaştırılması (332078). Retrieved from https://tez.yok.gov.tr/UlusalTezMerkezi/giris.jsp

Stien, L.H., Bratland, S., Austevoll, I., Oppedal, F., \& Kristiansen, T.S. (2007) A video analysis procedure for assessing vertical fish distribution in aquaculture tanks. Aquacultural Engineering, 37(2), 115-124. https:// doi.org/10.1016/j.aquaeng.2007.03.002

Waggett, R.J., \& Buskey, E.J. (2007). Calanoid copepod escape behavior in response to a visual predator. Marine Biology, 150(4), 599-607. https://doi.org/10.1007/s00227-006-0384-3

Xu, J., Liu, Y., Cui, S., \& Miao, X. (2006). Behavioral responses of tilapia (Oreochromis niloticus) to acute fluctuations in dissolved oxygen levels as monitored by computer vision. Aquacultural Engineering, 35(3), 207217. https://doi.org/10.1016/j.aquaeng.2006.02.004 